\title{
Toxicity of ascaridole from Chenopodium ambrosioides in mammalian mitochondria
}

\author{
Lars Gille $^{1 *}$, Lianet Monzote ${ }^{2}$, Werner Stamberg ${ }^{1}$, Katrin Staniek ${ }^{1}$ \\ From 16th Scientific Symposium of the Austrian Pharmacological Society (APHAR) \\ Vienna, Austria. 25-27 November 2010
}

\begin{abstract}
Background
Chenopodium ambrosioides has been used in traditional American medicine against parasitic diseases. Its essential oil (EO) is still used to treat leishmaniasis although it exhibits toxic effects in mammalian cells. Therefore, we studied the toxic mechanism of EO and its major pure ingredients (carvacrol, caryophyllene oxide and ascaridole) in mammalian cells and mitochondria.
\end{abstract}

\section{Methods}

Ascaridole was synthesized from alpha-terpinene and characterized by NMR and IR spectroscopy. The toxic effects of these compounds on macrophages from $\mathrm{BALB} / \mathrm{c}$ mice and on the bioenergetics of submitochondrial particles from bovine heart (SMP) and rat liver mitochondria (RLM) were studied. Toxic radical intermediates arising from the endoperoxide ascaridole were characterized by ESR spectroscopy.

\section{Results}

The MTT assay, which relies on mitochondrial function, revealed that caryophyllene oxide $\left(\mathrm{IC}_{50}=9.7 \pm 4 \mu \mathrm{M}\right)$ and ascaridole $\left(\mathrm{IC}_{50}=32 \pm 8 \mu \mathrm{M}\right)$ inhibited the survival of peritoneal macrophages from BALB/c mice in vitro more than the EO. In SMP we observed that all products inhibited mitochondrial respiration stronger for complex I than for complex II substrates. Most active in this respect was caryophyllene oxide, which preferably inhibited the complex I activity $\left(\mathrm{IC}_{50}=92 \pm 6 \mu \mathrm{M}\right)$. The pure compounds were more inhibitory for oxidative phosphorylation in RLM than EO. In the absence of $\mathrm{Fe}^{2+}$, ascaridole $\left(\mathrm{IC}_{50}>612 \mu \mathrm{M}\right)$ was less toxic to RLM than other major ingredients. However, it was shown that $\mathrm{Fe}^{2+}$ potentiated the toxicity of $\mathrm{EO}$ and ascaridole on oxidative phosphorylation of RLM. Evidence for the formation of carbon-centered radicals in the presence of $\mathrm{Fe}^{2+}$ has been obtained by ESR/spin trapping. To explore the route of ascaridole activation different iron-containing proteins were tested by ESR/spin trapping. Neither reduced nor oxidized mitochondrial cytochrome $\mathrm{c}$ as well as oxidized hemin were able to cleave ascaridole significantly. However, reduced hemin efficiently produced carboncentered radicals from ascaridole. Since detoxification of ascaridole by mammalian antioxidative enzymes is rather slow, hemin-mediated ascaridole cleavage contributes to its toxicity.

\section{Conclusions}

These data suggest that the toxicity of the essential oil from Chenopodium ambrosioides is partially related to the inhibition of the respiratory chain preferably by caryophyllene oxide while the toxicity of the antiparasitic agent ascaridole is dependent on the availability of redox-active iron.

\section{Author details}

'Molecular Pharmacology and Toxicology Unit, Department of Biomedical Sciences, University of Veterinary Medicine, 1210 Vienna, Austria. ${ }^{2}$ Institute of Tropical Medicine "Pedro Kouri", 11500 Havana City, Cuba.

Published: 16 November 2010

doi:10.1186/1471-2210-10-S1-A10

Cite this article as: Gille et al.: Toxicity of ascaridole from Chenopodium ambrosioides in mammalian mitochondria. BMC Pharmacology 2010 10(Suppl 1):A10.

\footnotetext{
* Correspondence: lars.gille@vetmeduni.ac.at

${ }^{1}$ Molecular Pharmacology and Toxicology Unit, Department of Biomedical

Sciences, University of Veterinary Medicine, 1210 Vienna, Austria

Full list of author information is available at the end of the article
} 